\title{
DESPRE BOGĂȚIA CUNOAȘTERII ȘI SĂRĂCIA ÎNȚELEPCIUNII
}

\author{
Mihaela MUNTEANU SISERMAN ${ }^{*}$ \\ Sabin SISERMAN ${ }^{* * *}$
}

\section{On the Wealth of Knowledge and the Scarcity of Wisdom}

\begin{abstract}
This paper aims at highlighting the specific differences of terms which are frequently considered to be synonyms. Knowledge, the genus, is the resultant of human existence filtered by physical and sensory, individual and collective experience. Wisdom, the differentia, is a synthesis, an individual or collective projection granting coherence to the knowledge accumulated. Thus, like any vector, wisdom is the existential element that provides direction, meaning and dimension to the human being.
\end{abstract}

Keywords: knowledge, wisdom, capital accumulation, meritocracy, morality.

„Cel care nu știe nimic, nu iubește nimic. / Cel care nu poate să facă nimic, nu înțelege nimic. / Cel care nu înțelege nimic, nu are nicio valoare. / Dar cel care înțelege, acela, totodată, iubește, observă, vede..."

(Paracelsus)

\section{Despre cunoaștere și înțelepciune, în general}

„Trăind în momentele de asalt ale primei revoluţii globale [...] cu posibilităţi imense ştiinţifice şi tehnologice pentru îmbunătăţirea condiţiei umane, bogaţi în cunoaştere, dar săraci în înţelepciune", se afirma într-un Raport al Consiliului Clubului de la Roma ${ }^{1}$. Deși relativ îndepărtată în timp, aserțiunea, formulată în urmă cu peste 25 de ani, pare să devină de mare actualitate în societatea românească, chiar dacă Raportul în sine sintetiza, elitist, o viziune globalistă asupra lumii.

Ideea nu este nouă, după cum ,nimic nu este nou sub soare”, ar spune Eclesiastul (Ecl. 1:9). Însuși Einstein afima că „Adevărata cunoaștere se dezvoltă din experiență”, adică din ceea ce numea Gotthold Ephraim Lessing ,înțelepciune”.

\footnotetext{
* Conf. univ. dr., Facultatea de Litere, Universitatea Tehnică din Cluj-Napoca, Centrul Universitar Nord Baia Mare, str. Victoriei,nr. 76, Baia Mare (ela_munteanu@yahoo.com).

** Filiala Județeană Maramureș a Asociației Comunelor din România.

1 Alexander King, Bertrand Schneider, Prima revoluţie globală. O strategie pentru supravieţuirea lumii. Un Raport al Clubului de la Roma, Bucureşti, Editura Tehnică, 1993, p. 202.
} 
Coborând pe scara evoluției conștiinței umane, dualismul „cunoaștere - înțelepciune", îl regăsim în gândirea budistă sub o formă primară, ușor de asimilat de ființa rațională, prin formularea sintetizatoare: „ceea ce afirmi trebuie să fie totuna cu ceea ce ai realizat, ai văzut, ai cunoscut tu însuți", , afirmația revendicând „trezirea individului din somnul ignoranței” prin experiențe senzoriale sau extrasenzoriale proprii.

Dar obiectivul prezentului demers nu este acela de a cola afirmații de maximă generalitate despre cunoaștere și înțelepciune, acestea fiind totuși necesare ca intermezzo în dezvoltarea subiectului.

Parafrazându-1 pe Paracelus putem spune: $C u$ cât mai multă cunoaștere este inerentă unui lucru, cu atât mai mare este întelepciunea ${ }^{3}$, și, implicit, să concluzionăm că această stare de fapt ar trebui să fie benefică ființei umane. Or, în acest moment al societății românești, lucrurile se complică și trebuie nuanţate.

\section{Cunoașterea și înțeleciunea în confruntare cu media actuală}

Într-o lume în care principalul descriptor sunt banii, asaltul tehnologic al ultimelor decenii a facut facil accesul individului la informație prin vectorii media. Aparent benefică, această conectare rapidă a individului la informație, s-a adeverit adesea nocivă, dat fiind faptul că amestecul polimorf dintre ,real-news” și „,fake-news”, omniprezent în media, a devenit imposibil de diferenţiat la nivelul omului de rând.

Peste nevoia de cunoaștere individuală, satisfăcută din plin de disponibilitățile tehnologice, s-a suprapus, parazit, războiul mediatic - cu scopuri și obiective mercantile - care transpar ușor în contextul informațiilor transmise, indiferent de vectorul informatic.

Acest război ,,asimetric" ", în esență, are un public-țintă definit clar adepții simoniei exacerbate -, dar care face însă multe victime colaterale, de regulă cetățenii simpli și onești, al căror ciclu existențial se închide zilnic în triada: familie- serviciu- odihnăs.

Pericolul și provocarea devine imensă: „,bombardarea” cu informație adevărată și / sau falsă ne face să ne construim propiul adevăr: existând ,adevărul meu” și ,,adevărul tău”, când confruntarea ideatică este personală sau ,adevărul nostru” și ,adevărul lor”, atunci când vorbim de ,partidism”.

Poate tocmai de aceea, o sinteză individuală a cunoștințelor și valorizarea lor într-o formă „,containerizată”, exprimată într-un sistem

\footnotetext{
2 Abrudan Ioan, Postfață, la Sabin Siserman Managementul de criză al entităților economice cu capital majoritar public deținut de unitățile administrativ teritoriale, vol. I Fundamente teoretice, Cluj-Napoca, Ed. Mega, 2016.

${ }^{3}$ Paracelsus, varianta neparafrazată: „Cu cât mai multă cunoaștere este inerentă unui lucru, cu atât mai mare este iubirea...."

${ }^{4}$ Un război asimetric este acel război în care există un dezechilibru substanțial între inamici sau care folosesc strategii și tactici total diferite.

${ }^{5}$ Este cunoscută formula existențială a omului modern: dodo - boulot - métro.
} 
axiologic al binelui și răului individual, devine din ce în ce mai greu de realizat.

Pe cale de consecință, și rezultanta opțiunilor axiologice obiectivată în „binele” și ,răul” colectiv este și va fi una puternic distorsionată.

3. Cunoașterea și înțelepciunea vs binomii ,a fi și a avea” și „bine și rău"

Î́n această „beție” a bombardamentului informațional, anumite aspecte par a fi abordate de media superfluu sau chiar ignorate. În prezent, tot ce ține de conținutul semantic al verbelor a fi și a avea (ca individ sau colectivitate), respectiv de conceptele bine și rău (individual sau social) se discută exclusiv din perspectiva paradigmei capitaliste, în care cei doi binomi distincți, enunțaţi anterior, ar avea un parcurs elipsoidal ${ }^{6}$, în care un focar l-ar reprezenta meritocrația, iar celălalt, moralitatea.

Se uită (oare nevinovat?) că românii au traversat în ultimii treizeci de ani o perioadă care, cel puțin tocmai aceste două sintagme meritocrație și moralitate au fost distorsionate, în goana după bunăstare, lăsând amprente adânci asupra caracterului lor.

Sunt tot mai frecvente vocile care afirmă că acumularea capitalului românesc din perioada postdecembristă nu a respectat, nu respectă și pare să nici nu dorească să respecte normele și principiile morale clamate în realizarea individuală, respectiv devenirea individuală prin muncă (în care sintagma „muncă” trebuie privită în formele ei cele mai variate prin care se poate crea plusvaloare pentru sine și societate). Fiindcă se prezumă că doar munca și efortul personal ar trebui să netezească accesul individului „de drept" la bunăstare și recunoaștere socială, prin toate valențele ei potențiale: munca fizică, munca intelectuală, munca organizatorică, educație sau pur și simplu prin acea „fulgurație pe cerul minții”, care aduce colectivităţii sau omenirii beneficii imense cum ar fi, spre exemplu, o invenție (vezi varianta romanțată referitoare la invenția banalului cui ${ }^{7}$ ). În același context, P. Dulfu (1991: 10-11) afirma: „Este știut că oamenii și-au îmbunătățit din ce în ce traiul numai prin ajutorul minţii lor iscoditoare, născocind mereu lucruri, unelte și meșteșuguri noi, cari să le fie de folos în viitor [...] Darul acesta 1au avut întotdeauna și-l au și astăzi, numai puțini, foarte puțini dintre muritori".

În contextul în care în ultimul deceniu, cu precădere în ultimii trei ani, asistăm în România, la un proces insidios de ,încercare de legitimare a capitalulului autohton", prin manevre absconse ale majorității media (privită ca pricipal vector de „transport” al cunoștintelor), în care pare să primeze

\footnotetext{
${ }^{7}$ Tudor Arghezi - Cuiul http://www.tudorarghezi.eu/opere/poezii/cuiul.html\#.XchCHq9oSUk
} 
eschiva de la morală și răspundere juridică privind modul realizării marilor acumulări de capital și poziții sociale.

\section{Cunoaștere și înțelepciune vs meritocrație și devenire individuală}

Realizarea individuală - prin muncă și drept - intens clamată ca sursă a bunăstării individuale, cu cca 140 de ani în urmă, de un primministru francez ${ }^{8}$ devine din nou foarte discutabilă. O scurtă retrospectivă asupra unei gândiri sintetizatoare a cunoștințelor, în vogă la vremea ei, dar dezavuată în prezent, ar fi, daca nu utilă, măcar moralizatoare?

Istoria „meritocratiei mioritice”, presupusă a fi realizată prin acumulări succesive de cunoștințe și bunuri pe cale cinstită, pare să se repete în prezent, în cazul României, reluată după o fractură de cca 40 de ani cât a durat perioada comunistă. Argumentațiile lui Adams Smith și Marie Joseph Louis Adolphe Thiers, referitoare la formarea capitalului cad, cu siguranță, în derizoriu în fața realității de azi din România.

Meritocrația actuală, „consolidată” pe bază de diplome, și „capitaliștii” noștri, populează intens scena social-politică românească și este suficient, uneori, o lectură a parcursului profesional al majorității „potenților” zilei din diferite zone ale activității social-politice și să constați că aceștia sunt „bogați în cunoaștere” doar prin ,,acumulări” de diplome și titluri academice de la instituții care nu trec, de cele mai multe ori, de „furcile caudine" ale comisiilor de autorizare / acreditare ARACIS"10, dar săraci în înțelepciune, expunându-și, nu de puține ori, mediatic mediocritatea. Oare de unde își iau puterea de a se considera atât de

8 Este vorba de Adolphe Thiers (1797-1877) „a fost un avocat, jurnalist, istoric și om politic francez. A deținut diferite funcții politice: prim-ministru în timpul lui LudovicPhilippe, președinte interimar al Franței, președinte al Consiliului de Miniștri în perioada Monarhiei din Iulie, deputat în perioada celei de a Doua Republici". (https://ro.wikipedia.org/wiki/Adolphe_Thiers)

9 Privită în contextul acestei paradigme, dihotomia profundă existentă în prezent între „cunoștințe” și „înțelepciune”, poate fi regăsită în replica adresată de Marx lui Marie Joseph Louis Adolphe Thiers: „După cum se ştie, în istoria reală, cucerirea, subjugarea, jaful şi asasinatul, într-un cuvînt violenţa [în acumularea capitalului, n.a.] joacă rolul de frunte. Dar în blajina economie politică a domnit întotdeauna idila. Dreptul şi munca au fost întotdeauna singurele mijloace de îmbogăţire, excepţie făcînd, bineînţeles, de fiecare dată « anul acesta ». În realitate, metodele acumulării, primitive sunt oricum vreţi, numai idilice nu".

http://etext.store/marx/capitalul/procesul/asa_numita_acumulare_primitiva/1_misterul_acu mularii_primitive

${ }^{10}$ În anul următor căderii dictaturii, în contextul deschiderii „privatizării” învățământului din România, un jurnalist al cărui nume nu îl mai rețin, parodia premonitoriu, în ziarul Tineretul Liber, decăderea iminentă a actului educaţional, într-un articol intitulat $\mathrm{La}$ facultate în satul meu natal. „Minunea” am văzut-o împlinită zece ani mai târziu, trecând printr-o localitate rurală, renumită pentru apele termale, pe frontispiciul unei clădiri scriind: Secția de balneologie, a unei universități în vogă la vremea respectivă. 
„înțelepți” încât să-și aroge dreptul de a legifera? Și, dacă da, în folosul cui legiferează?

\section{5. În loc de concluzii}

Putem conchide că noi, românii, am devenit într-un orizont temporal extrem de scurt foarte „bogați în cunoștințe”, dar, cu siguranță, „săraci în înțelepciune", atâta timp cât suportăm impostura mediatizată la extrem și uneori aplaudăm (de bunăvoie sau siliți) mediocritatea numită în posturi de conducere.

Încotro ne îndreptăm, dacă acceptăm resemnați această stare de fapt? Poate ar trebui să ne oprim pentru o clipă din voiajul existențial, să înțelegem că, deși sorții devenirii sociale sunt de partea noastră ar trebui, cu mai multă osârdie, să încercăm să pătrundem înțelepciunea lui Lucius Annaeus Seneca: Ignoranti, quem portum petat, nullus suus ventus est ${ }^{11}$.

\section{Bibliografie}

Abrudan, Ioan, „Postfață” la Managementul de criză al entităților economice cu capital majoritar public deținut de unitățile administrativ teritoriale. Vol. I Fundamente teoretice (autor Sabin Siserman), Cluj-Napoca, Editura Mega, 2016

Dulfu, P., Foloasele învățăturii, ediția a doua, București, Institutul de arte grafice C. Sfetea, 1911

King, Alexander, Bertrand Schneider, Prima revoluţie globală. O strategie pentru supravieţuirea lumii. Un Raport al Clubului de la Roma, Bucureşti, Editura Tehnică, 1993

\section{Sitografie}

(consultată între 20.10-10.11.2019)

https://ro.wikipedia.org/wiki/R\%C4\%83zboi_asimetric

https://ro.wikipedia.org/wiki/Adolphe_Thiers

http://etext.store/marx/capitalul/procesul/asa_numita_acumulare_primitiva/1_miste rul acumularii primitive

\footnotetext{
${ }^{11}$ Niciun vânt nu este favorabil pentru cel care nu știe spre ce port se îndreaptă.
} 